\title{
Cuban Connection: Regional Role for Florida's Manatees
}

\author{
Anmari Alvarez-Alemán ${ }^{1,2}$, James D. Austin ${ }^{1,3}$, Charles A. Jacoby ${ }^{1,4}$ and \\ Thomas K. Frazer ${ }^{1,5 *}$
}

${ }^{1}$ School of Natural Resources and Environment, Institute of Food and Agricultural Sciences, University of Florida, Gainesville, FL, United States, ${ }^{2}$ Centro de Investigaciones Marinas, Universidad de la Habana, La Habana, Cuba, ${ }^{3}$ Department of Wildlife Ecology and Conservation, Institute of Food and Agricultural Sciences, University of Florida, Gainesville, FL, United States, ${ }^{4}$ Soil and Water Sciences Department, Institute of Food and Agricultural Sciences, University of Florida, Gainesville, FL, United States, ${ }^{5}$ Fisheries and Aquatic Sciences Program, School of Forest Resources and Conservation, Institute of Food and Agricultural Sciences, University of Florida, Gainesville, FL, United States

\section{OPEN ACCESS}

Edited by:

E. Christien Michael Parsons, George Mason University, United States

Reviewed by:

Laura J. May-Collado, University of Vermont, United States Lorelei Diane Crerar, George Mason University, United States

*Correspondence: Thomas K. Frazer frazer@ufl.edu

Specialty section: This article was submitted to Marine Conservation and Sustainability,

a section of the journal Frontiers in Marine Science

Received: 08 May 2018 Accepted: 31 July 2018 Published: 21 August 2018

Citation:

Alvarez-Alemán A, Austin JD, Jacoby CA and Frazer TK (2018) Cuban Connection: Regional Role for Florida's Manatees.

Front. Mar. Sci. 5:294 doi: 10.3389/fmars.2018.00294
The status of the West Indian manatee [Trichechus manatus (Linnaeus, 1758)] remains enigmatic. The International Union for Conservation of Nature classifies the species as "Vulnerable" and the two subspecies [T. m. manatus (Linnaeus, 1758) and T. m. latirostris (Harlan, 1824)] as "Endangered." The U.S. Fish and Wildlife Service now classifies West Indian manatees as "Threatened" primarily due to increased numbers of T. m. latirostris. Fully resolving the status of the species will require a better understanding of its population biology throughout the broader Caribbean region, especially the form and strength of genetic and demographic connections. Genetic studies indicate limited interbreeding among recent generations of groups of manatees separated by unsuitable coastal habitat or large expanses of open water, such as the Florida Straits. However, documentation of two, independent immigrations from Florida to Cuba within one generation raises the possibility of important demographic connections, especially if the number of manatees in Cuba is small. In addition, these events may foreshadow a change in the role that Florida's manatees play in effective conservation of $T$. manatus throughout its Caribbean range, with the potential for further connections as numbers of manatees in Florida increase and the availability of suitable habitat and food decreases.

Keywords: West Indian manatee, Trichechus manatus, genetic connectivity, demographic connectivity, conservation

The status of the West Indian manatee [Trichechus manatus (Linnaeus, 1758)] is a concern. The species is classified as "Vulnerable" by the International Union for Conservation of Nature, and two subspecies [T. m. manatus (Linnaeus, 1758) and T. m. latirostris (Harlan, 1824)] are classified as "Endangered" (https://doi.org/10.2305/IUCN.UK.2008.RLTS.T22103A9356917.en). Recently, the U.S. Fish and Wildlife Service reclassified the West Indian manatee as "Threatened" rather than "Endangered" primarily due to a marked increase in numbers of T. m. latirostris, the Florida subspecies, over the last 25 years (Federal Register, 2017). Overall, the status of T. manatus throughout its broader Caribbean range remains uncertain because estimates of numbers and demographic trends for many populations are based on anecdotal information or gray literature (Self-Sullivan and Mignucci-Giannoni, 2012; Alvarez-Alemán et al., 2018). 
One key uncertainty is whether manatees in different Caribbean regions should be managed as distinct populations because unsuitable coastal habitat or large expanses of marine water may preclude movements that establish genetic and demographic connectivity (Garcia-Rodriguez et al., 1998; Lowe and Allendorf, 2010).

Studies of genetic markers document several phylogeographic patterns for T. manatus among and within regions of the Caribbean. Sequences in mitochondrial deoxyribonucleic acids (mtDNA) identified three distinct lineages occupying (i) Florida and the West Indies, (ii) the Gulf of Mexico to the northern Caribbean coast of South America, and (iii) the northeast Atlantic coast of South America (Garcia-Rodriguez et al., 1998). Examination of mtDNA from additional manatees identifies a similar set of lineages and suggests historical barriers to dispersal that separate the Dominican Republic and Puerto Rico from other parts of the Greater Antilles (Vianna et al., 2006). Variation in microsatellites also differentiates manatees in Mexico from those in Florida, with minimal evidence of interbreeding, and the results further identify two relatively distinct groups within Mexico, a mixing zone with alleles from both of those groups, and the potential influence of migrants from Belize (Nourisson et al., 2011). In Belize, mtDNA and microsatellite markers from groups of manatees separated by $<100 \mathrm{~km}$ indicate genetic differentiation characteristic of isolated populations (Hunter et al., 2010). Furthermore, manatees in Belize appear unrelated to manatees in Florida (Hunter et al., 2010). Within the eastern Caribbean, a study that combined mtDNA and nuclear microsatellites provides support for the separation of T. m. latirostris in Florida from T. m. manatus in Puerto Rico (Hunter et al., 2012). In contrast, a study of mtDNA in manatees from Cuba suggests historical links to manatees in Florida and the Greater Antilles and the possibility of a link to Belize (Hernández Martínez et al., 2013). Within Florida, microsatellite markers yield very weak evidence of genetic differentiation among the four recognized management units (Tucker et al., 2012). Overall, the results of existing genetic analyses indicate reduced dispersal among many parts of the Caribbean and levels of dispersal within specific localities that appear to exhibit a positive relationship with increased abundance of manatees and availability of suitable corridors for dispersal. However, these studies of genetics do not assess demographic connectivity as defined by the effect of immigrants on vital rates, which is an important element in effective conservation of T. manatus (Lowe and Allendorf, 2010).

Initial evidence of a potentially important connection comes from photographs of a female and calf in Florida in 2006 and a subsequent sighting of these manatees in Cuban waters near Havana in 2007 (Alvarez-Alemán et al., 2010). In November 2017, another adult and a calf were photographed along Cuba's northwestern coast near Havana (Figure 1A), and the U.S. Geological Survey's Manatee Individual Photo-identification System positively identified the adult's two sets of scars as belonging to FM582 (Figure 1B). Records of FM582 in southwest Florida span 11 years, and it was sighted near Fort Myers, Florida in January 2017. Calves were near FM582 in multiple years, which suggests she is a female. Both she and the calf likely traveled from Florida to Cuba because calves depend on their mothers for 12 winters (O'Shea et al., 1995). These sightings represent direct evidence of connectivity between two geographically separated

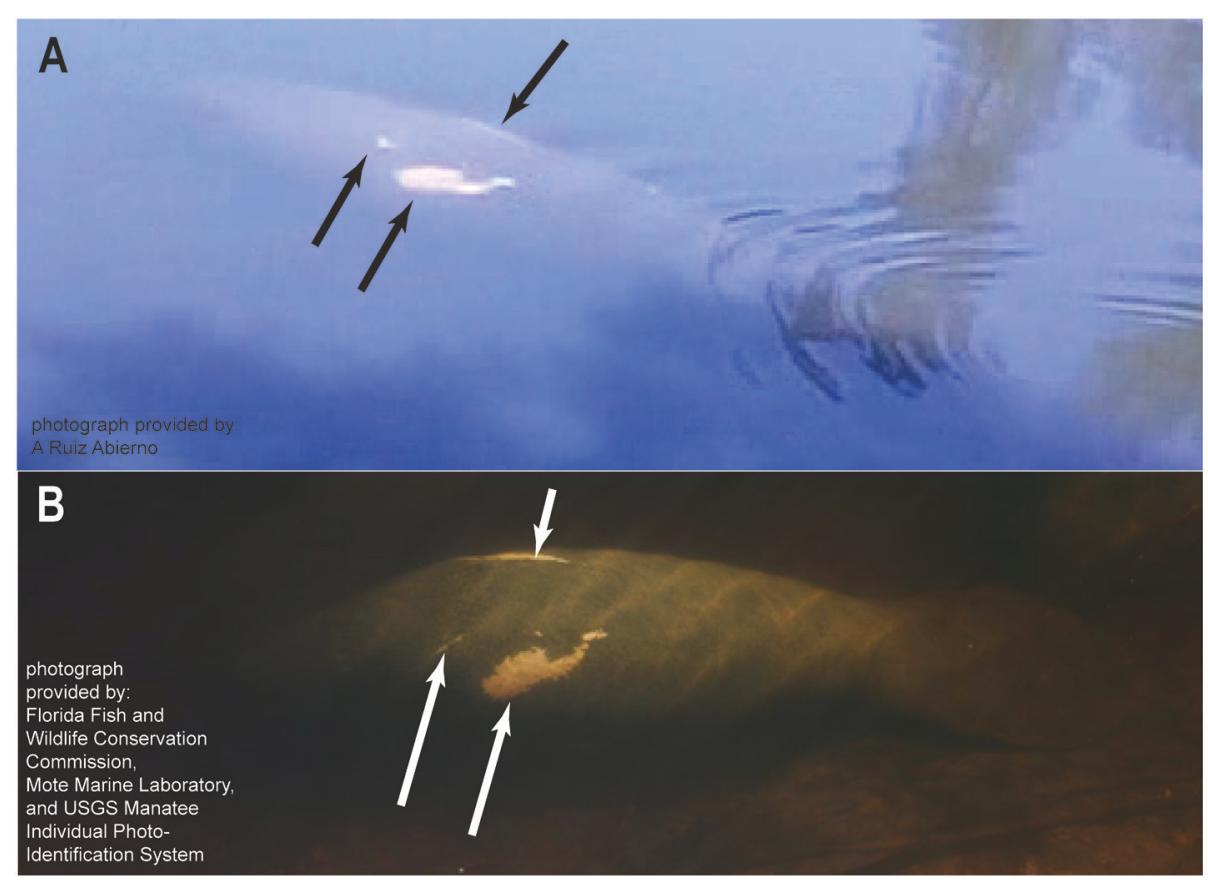

FIGURE 1 | Photographs of a manatee taken in Cuba (A) and in southwest Florida (B) showing the scars that identified it as FM582. Permissions shown on photographs. 
populations, and two, independent immigrations within a decade (i.e., less than a generation) suggest that such movements may have demographic import. In conjunction with shared mtDNA haplotypes (Hernández Martínez et al., 2013), such sightings suggest that populations of manatees in Florida, Cuba, and other Caribbean regions may not remain evolutionarily or demographically distinct if manatees successfully cross expanses of open water, such as the Florida Straits. Increased connectivity in the Caribbean region engenders important ramifications for conservation, especially selecting the optimal number of management units and incorporating source-sink dynamics into decisions about levels of protection (Pulliam, 1988; Lowe and Allendorf, 2010).

Several challenges prevent a full interpretation of the importance of these sightings. Demographic connectivity requires the migrants to exert an effect on vital rates in the population they enter (Lowe and Allendorf, 2010). Unfortunately, there is no information on the fate of the manatees that reached Cuba. In addition, the size of the Cuban population of T. manatus is uncertain (Alvarez-Alemán et al., 2018), so an estimate of the relative contribution of these immigrants cannot be derived. Programs to address these issues would advance conservation of the Antillean manatee. For example, rigorous censuses of manatees in Cuba would provide an estimate of the size of the population, and a program that involves professional and citizen scientists in the development, maintenance, and application of a photographic identification system would help identify additional immigrants and clarify their fates. Regardless of the fate of the recent immigrants, the two sightings suggest that the regional significance of Florida's population of manatees may be increasing as numbers around the state rise and the availability of suitable habitat and food

\section{REFERENCES}

Alvarez-Alemán, A., Alfonso, E. G., Martin-Vianna, Y. F., Gonzalez, Z. H., Domenech, R. E., Hurtado, A., et al. (2018). Status and conservation of manatees in Cuba: historical observations and recent insights. Bull. Mar. Sci. 94, 313-327. doi: 10.5343/bms.2016.1132

Alvarez-Alemán, A., Beck, C. A., and Powell, J. A. (2010). First report of a Florida manatee (Trichechus manatus latirostris) in Cuba. Aquat. Mamm. 36, 148-153. doi: 10.1578/AM.36.2.2010.148

Federal Register (2017). Endangered and Threatened Wildlife and Plants; Reclassification of the West Indian Manatee From Endangered to Threatened. Federal Register: the daily journal of the United States, Fed. Reg. 64, April 6, 2017. Washington, DC. Accessed (29 April, 2018).

Garcia-Rodriguez, A. I., Bowen, B. W., Domning, D., Mignucci-Giannoni, A. A., Marmontel, M., Montoya-Ospina, R. A., et al. (1998). Phylogeography of the West Indian manatee (Trichechus manatus): how many populations and how many taxa? Mol. Ecol. 7, 1137-1149. doi: 10.1046/j.1365-294x.1998. 00430.x

Hernández Martínez, D., Alvarez-Alemán, A., Bonde, R. K., Powell, J. A., and García-Machado, E. (2013). Diversidad haplotípica en el manatí Trichechus manatus en Cuba: resultados preliminares. Rev. Invest. Mar. 33, 58-61. doi: 10.13140/2.1.2922.5601

Hunter, M. E., Auil-Gomez, N., Tucker, K. P., Bonde, R. K., Powell, J., and McGuire, P. M. (2010). Low genetic variation and evidence of limited dispersal in the regionally important Belize manatee. Anim. Conserv. 13, 592-602. doi: $10.1111 /$ j.1469-1795.2010.00383.x decreases (Littles, 2016). Overall, effective conservation of $T$. manatus will be difficult without close cooperation among researchers in all relevant countries and a supportive political environment (Stone, 2017).

\section{ETHICS STATEMENT}

This article was based on photo-documented observations only. There was no direct handling or manipulation of animals. As such, the work is exempt from IACUC oversight.

\section{AUTHOR CONTRIBUTIONS}

AA-A, JA, CJ, and TF contributed equally to the preparation of this manuscript.

\section{FUNDING}

Funding for this work was provided by the University of Florida's Institute of Food and Agricultural Sciences.

\section{ACKNOWLEDGMENTS}

Many thanks to the people from the Almendares River community who informed us about the manatee sighting promptly. We are grateful to A Ruiz Abierno who obtained and provided the video taken in Cuba. Thanks to C Beck who verified the match to FM582 and to K Rood and S Barton who scoured the Manatee Individual Photo-Identification system, provided the image from southwest Florida, and supplied the history of sightings in Florida. We also thank Sea to Shore Alliance for supporting manatee conservation in Cuba.
Hunter, M. E., Mignucci-Giannoni, A. A., King, T. L., Tucker, K. P., Bonde, R. K., and McGuire, P. M. (2012). Puerto Rico and Florida manatees represent genetically distinct groups. Conserv. Genet. 13, 1623-1635. doi: 10.1007/s10592-0120414-2

Littles, C. B. J. (2016). An Investigation of Wintering Florida Manatee Population Dynamics at Multiple Scales. Ph.D. dissertation, School of Natural Resources and Environment, University of Florida, Gainesville, FL.

Lowe, W. H., and Allendorf, F. W. (2010). What can genetics tell us about population connectivity? Mol. Ecol. 19, 3038-3051. doi: 10.1111/j.1365-294X.2010.04688.x

Nourisson, C., Morales-Vela, B., Padilla-Saldivar, J., Tucker, K. P., Clark, A. N., Olivera, L. D., et al. (2011). Evidence of two genetic clusters of manatees with low genetic diversity in Mexico and implication for their conservation. Genetica 139, 833-842. doi: 10.1007/s10709-0119583-Z

O'Shea, T. J., Ackerman, B. B., and Percival, H. F. (1995). "Population biology of the Florida manatee: an overview," in Population Biology of the Florida Manatee, eds T. J. O'Shea, B. B. Ackerman, and H. F. Percival (Washington, DC: National Biological Service Information and Technology Report), 280-287.

Pulliam, H. R. (1988). Sources, sinks, and population regulation. Am. Nat. 132, 652-661. doi: $10.1086 / 284880$

Self-Sullivan, C., and Mignucci-Giannoni, A. A. (2012). "West Indian manatees (Trichechus manatus) in the wider Caribbean region," in Sirenian Conservation: Issues and Strategies in Developing Countries, eds E. M. Hines, J. E. III Reynolds, 
L. V. Aragones, A. A. Mignucci-Giannoni and M. Marmontel (Gainesville, FL: University Press of Florida), 36-46.

Stone, R. (2017). Political chill reverses thaw in U.S.-Cuban science. Science 358:1115. doi: 10.1126/science.358.6367.1115

Tucker, K. P., Hunter, M. E., Bonde, R. K., Austin, J. D., Clark, A. M., McGuire, P. M., et al. (2012). Low genetic diversity and minimal population substructure in the endangered Florida manatee: implications for conservation. J. Mammal. 93, 1504-1511. doi: 10.1644/12-MAMMA-048.1

Vianna, J. A., Bonde, R. K., Caballero, S., Giraldo, J. P., Lima, R. P., Clark, A., et al. (2006). Phylogeography, phylogeny and hybridization in trichechid sirenians: implications for manatee conservation. Mol. Ecol. 15, 433-447. doi: 10.1111/j.1365-294X.2005. 02771.x
Conflict of Interest Statement: The authors declare that the research was conducted in the absence of any commercial or financial relationships that could be construed as a potential conflict of interest.

The reviewer LC and handling editor declared their shared affiliation at the time of the review.

Copyright $\odot 2018$ Alvarez-Alemán, Austin, Jacoby and Frazer. This is an open-access article distributed under the terms of the Creative Commons Attribution License (CC $B Y)$. The use, distribution or reproduction in other forums is permitted, provided the original author(s) and the copyright owner(s) are credited and that the original publication in this journal is cited, in accordance with accepted academic practice. No use, distribution or reproduction is permitted which does not comply with these terms. 